\title{
Proposed Regulations for Enforcement of the Purports of Binding Banking Documents in Rastin Banking
}

\author{
Bijan Bidabad ${ }^{\mathrm{I}}$ \\ Saeid Abdollahi ${ }^{2}$ \\ Mahshid Sherafati ${ }^{3}$ \\ Roohollah Mohammadi ${ }^{4}$
}

\begin{abstract}
To facilitate and accelerate the enforcement of binding banking documents and distribute the enforcement burden of the registration offices of the State Organization for Registration of Deeds and Properties, courts, and judicial authorities, a new mechanism for "enforcement of the purports of binding banking documents in Rastin Banking" was designed. This mechanism can lead to positive and essential effects toward creating public trust in financial obligations and increasing the speed of collecting demands, in order to remove the problems resulting from enforcement of the purports of binding documents. In this paper, the proposed regulations are presented in two drafts of "The Bill for Enforcement of the Purports of Binding Banking documents in Rastin Banking” and "The Bylaw for Enforcement of the Purports of Binding Banking Documents and Handling Complaints against Executive Operations in Rastin Banking”. The newly designed method has been compiled considering all financial, legal, and executive issues. In the proposed regulations, a part of the executive path for enforcement of the purports of binding banking documents is transferred from the "Document Registration Unit" into a newly established unit called the "Bank Documents Execution Unit" (BDEU), located in every bank, and this new unit will follow the enforcement of the purports of binding banking documents, instead of the "Document Registration Unit". All the legal necessities, the necessary cooperation with the judicial authorities, and the necessary procedures for hearing and settlement have all been designed to not let any spoiling of the rights of the parties, while also working efficiently. This procedure is a model that can be adapted for other countries, especially those countries that have a large number of legal disputes and the process of dispute settlement is very lengthy and cumbersome. Since the Administration of Justice is the main factor to promote all the other social and economic circumstances, the proposed model can prepare a way to improve the social and economic well-being.
\end{abstract}

Keywords: Rastin Banking, Rastin Profit and Loss Sharing (PLS), Enforcement of the Purports of Documents, Banking Documents.

\section{Introduction}

Rastin Banking, through observing Islamic banking principles and eliminating any doubt in terms of usury in the banking operation, while providing health and creating public trust, with the aid of the special designed mechanisms, can lead to positive

1 (B.A., M.Sc., Ph.D., Post-Doc.) Professor of Economics and Chief Islamic Banking Advisor, Bank Melli Iran, bijan@bidabad.com, Bidabad@yahoo.com, http://www.bidabad.com

${ }^{2}$ Legal Expert, Bank Melli Iran, legal0352@bmi.ir

${ }^{3}$ MBA Department, Management Faculty, Multimedia University, Malaysia, mahshidsherafati@gmail.com

${ }_{5}^{4} \mathrm{CEO}$ at Novin-Pajoohan Research Institute, Tehran, Iran. r_mohamadi58@yahoo.com

${ }^{5}$ See: Bidabad, Bijan, New Operational Islamic Banking System, Volume One, Theoretical Foundations, LAP Lambert Academic Publishing, OmniScriptum GmbH \& Co. KG, 2014, ISBN: 978-3-659-54463-7.

Bidabad, Bijan, New Operational Islamic Banking System, Volume Two, Applicational Issues, LAP Lambert Academic Publishing, OmniScriptum GmbH \& Co. KG, 2014, ISBN: 978-3-659-55210-6. 
and essential effects on the economic growth and welfare, as well as the money and capital markets ${ }^{6}$. Rastin Banking has been designed based on the operational, financial, economic, ethical, social, legal, international, and organizational principles, which all have been resulted from rational, human, Islamic and ethical teachings, based on the latest human scientific achievements in the fields of science and technology, and with the purpose to develop the economy and the banking system of the country. The advantages of Rastin Banking are so widespread in all relevant fields so that it can be considered as the main component in the reformation of the banking structure of the country. Therefore, to protect the obtained achievements, the drafts of the bill ${ }^{7}$ and the executive bylaw ${ }^{8}$ of Rastin Banking have been compiled.

In this paper, only a part of Rastin Banking regulations, in the field of the proposed regulations for the enforcement of the purports of binding banking documents, is addressed. These regulations have been codified and adopted from "the Bylaw for Enforcement of the Purports of Binding Banking Documents and Handling Complaints against Executive Operations" through matching the operations with the arrangements and purports of the stated bylaw ${ }^{9}$, and its definitions and terms have been employed.

Enforcement of the purports and subjects of the official documents, without referring to the judicial courts, and through the bank itself, is one of the characteristics of the official documents, which has been stipulated in Articles 92 and 93 of the Registration Law. The official document, according to the definition of Article I287 of the Civil Law, refers to the documents, which have been drawn up in the Office for Registration of Deeds and Properties, notary public offices, or other official authorities based on their qualification and according to legal regulations. Except for the documents, for which specific regulations have been enacted, and the writ of execution for them is issued in the Offices for Registration of Deeds and Properties or the related authorities, other binding documents and their writ of execution are generally issued in notary public offices. Article 34 of the amendment I386 of the Registration Law, which is related to the conditional and mortgage transactions and also the transactions with refund right that are concluded between individuals in notary public offices, has entitled the creditor to request for issuance of the writ of execution by referring to the notary public office, which has drawn up the document ${ }^{10}$. At the present time, arrangements are made for enforcement, through the registration unit of the State Organization for Registration of Deeds and Properties after issuance of the writ of execution by notary public offices.

In Rastin Banking, all contracts, which are concluded and exchanged between the parties in the bank and along with the execution of Rastin Banking, are regarded as the binding official documents, and if the proposed bill and executive bylaw are enacted by the competent authorities, all the banks can collect their claims arising from the contracts and commercial documents, through the "Bank Documents Execution Unit (BDEU)". In general, in the proposed regulations, the executive path with respect to the banking documents will be transferred to a newly established unit, called the BDEU in the bank, and after issuance of the writ of execution, the purports of the document will be enforced through the BDEU and by the bank officers for execution of the banking documents, rather than by the registration units. Therefore, in the mortgage and conditional contracts as well as the other specified contracts, which are concluded alongside the execution of Rastin Banking, in case the debtor does not pay his/her debt on the due date indicated in the document, the bank can request the notary public office to issue the writ of execution, and the notary public office will send the writs of execution for enforcement of the purports of the document to the $\mathrm{BDEU}$ of the bank and in case the debtor does not pay his/her debt, the BDEU will take action regarding the collection of its claims after evaluating the object of transaction through bidding. The details of the executive operation, the framework of the administrative and supervisory organization, and the method of performing the executive operation will be based on the following codified regulations in Rastin Banking.

Since the Administration of Justice is the main factor to promote all the other social and economic circumstances, the proposed

\footnotetext{
${ }^{6}$ For more details with regard to Rastin Banking texts and documents, refer to http://www.bidabad.com, under Rastin Banking section.

${ }^{7}$ Bidabad, Bijan., Amirostovar, Azarang., Abdollahi, Saeid., Allahyarifard, Mahmoud., Pordel, Eskandar., Heydari, Maryam., Shafiei, Alireza., and Pourbehrouz, Mohammad-Ali. (2012). The Draft Bill of Rastin Banking, Bank Melli Iran

${ }^{8}$ Bidabad, Bijan., Amirostovar, Azarang., Abdollahi, Saeid., Allahyarifard, Mahmoud., Pordel, Eskandar., Heydari, Maryam., Shafiei, Alireza., and Pourbehrouz, Mohammad-Ali. (2012). The Draft of the Executive Bylaw of Rastin Banking, Bank Melli Iran
}

${ }^{9}$ The Bylaw for Enforcement of the Purports of Binding Official Documents and Handling Complaints against Executive Operations in Rastin Banking, The Bylaw for the Reform Law of the Law of Holding the Public and Revolutionary Courts, Ratified on 29.01.2003

The Bylaw for Enforcement of the Purports of Binding Official Documents, Amendments of Articles 34, 35, 36, Quoted from No. 18509, 14.09.2008, Official Gazette No. 1/87/5553, 09.09.2008.

${ }^{10}$ Najafi, Iraj. (2010). The Role and Position of Notary Public Offices in Enforcement of the Purports of Binding Official Documents, Notaries Monthly Journal, No. 104, http://www.notary.ir/content-news-letter/436 
model can prepare a way to the social and economic well-being. This procedure is a model that can be adapted for other countries, especially those countries that have a large number of legal disputes and the process of dispute settlement is very lengthy and cumbersome.

Codifying the law and regulations is a highly sophisticated task, and the art of codification can be examined after scrutinizing the full text of the law and enforcement of the law for a relatively more extended period. This is not, in fact, accessible for the new law procedures and they need to be criticized in order to remove the probable deficiencies. This was the cause to make the authors obliged to offer the complete text.

\section{The Proposed Bill for Enforcement of the Purports of Binding Banking Documents}

Article I - All the contracts, which are concluded and exchanged among the parties in banks and along with the enforcement of Rastin Banking, are regarded as the official and binding documents that are executed by the related executive officers.

Article 2 - Regarding all the mortgage and conditional transactions as well as the other transactions, which have been mentioned in Article 33 of the Registration Law, for the movable and immovable properties, concluded toward the execution of this law, in case the debtor does not pay his/her debt on the due date indicated in the document, the bank can request the notary public office to issue the writ of execution. The notary public office is obliged to send the writs of execution for enforcement of the purports of the document to the Bank Documents Execution Unit (BDEU). In case, the debtor does not pay his/her debt within IO days of the notification date of the writ of execution of the BDEU, the BDEU by evaluating the whole object of the transaction and finalization, within maximum 2 months, will collect its claims through holding a bid and based on the legal claim, and will return the surplus to the mortgagor.

Note: In case a property or an asset is pledged as debt, obligation, or guarantee in the execution of this law (Rastin Banking), the regulations of this law will be applied.

Article 3 - The framework of the administrative and supervisory organization, and the method of performing the executive operation, including notification of the writ of execution, seizure of the surplus of the object of mortgage, holding the bid, waiver of the mortgage, the process of complaint against executive operations and the dispute-settlement authorities, completion of the executive operation, issuance of the writ of execution and the executive operation based on the debt documents, eviction of the property and travel ban of the debtor with no property, and other cases, will be performed based on the Bylaw for Enforcement of the Purports of Binding Banking Documents and Handling Complaints against Executive Operations in Rastin Banking.

Note: The Bylaw for Enforcement of the Purports of Binding Banking Documents and Handling Complaints against Executive Operations in Rastin Banking will be prepared by the Central Bank, at most within 3 months of the enactment of this law, and will be enacted by the government's Council of Ministers.

Article 4 - All the real persons and legal entities, including the notary public offices, BDEUs and Offices for Registration of Deeds, the police force, all governmental and non-governmental institutions and bodies, and the persons for whom applicability of the law requires the expression of the name, are obliged to enforce the purports of the writs of execution and arrest warrants issued by the BDEU as well as their related executive requirements according to this law and the Bylaw for Enforcement of the Purports of Binding Banking Documents and Handling Complaints against Executive Operations in Rastin Banking.

Article 5 - For procedural and substantive handling of all the complaints arising from the executive operation, a committee is formed in every bank and named as "the preliminary committee for handling complaints against executive operations", which comprises of three principal members, including a court judge elected by the director general of the Administration of Justice of the province, an experienced expert assigned by the director general of Organization for Registration of Deeds and Properties of the province, and an informed representative of the bank, who is assigned by the board of directors of the bank. In addition, three alternate members, whose title and assignment procedure will be the same as the principal members, will be included.

Note: Regarding non-governmental banks, the informed representative mentioned in this article is selected and introduced at the request of the bank and from the qualified personnel of one of the governmental banks and by the board of directors of the latter bank.

Article 6 - The decisions of the preliminary committee are appealable within 20 days of the notification date and will be readdressed in the appeal committee of handling complaints against executive operations. In case either of the parties does not appeal until the due date, the issued decision will be final and binding. 
Article 7 - The preliminary and appeal committees will organize the sessions according to the executive bylaw and will hear the case and issue the decision accordingly. The decisions of the committee should be reasonable and documented based on the governing laws and regulations.

Article 8 - The appeal committee has three principal members, including a court judge assigned by the director general of the Administration of Justice of the province, an experienced expert in the related subjects, who is assigned by the director general of the State Organization for Registration of Deeds and Properties, and an informed and competent representative of the bank assigned by the director general of the Central Bank, who will be placed in the Central Bank. The issued decision of the appeal committee will be final and binding.

Note I: Hearing in the appeal committee includes two forms of procedural and substantive.

Note 2: The appeal committee will have three alternate members, whose titles and assignments will be the same as the principal members.

Article 9 - Each of the members of the preliminary and appeal committees is assigned for 3 years, and their re-assignment is permissible. In the absence of the principal members, the alternate members will perform duties instead of them.

Article I0 - Dismissal of the members of the preliminary committee will be suggested by the board of directors of the bank, and dismissal of the members of the appeal committee will be suggested by the director general of the Central Bank and approved by the assigning authorities.

Article II - In case necessary and as the case may be, the preliminary and appeal committees for handling complaints against executive operations can have different branches, by the discretion of the board of directors of the bank or the Central Bank.

Article 12 - None of the members of the preliminary committees can be the member of the appeal committees and vice versa. They also cannot hear or make comments on cases at the upper stage, when they have previously made comments at the lower stage.

Article I3 - The establishment and the number of branches of the preliminary and appeal committees, assignment and dismissal of the members, determination of the alternate members, rejection of the members, qualification of the members, the methods of hearing, issuance, enforcement, amendment, and change in the scope of qualification of the committees, dissolution procedure, notification process of the decisions, recording of sessions, and other cases, which have not been specified in the law, will be based on the Bylaw for Enforcement of the Purports of Binding Banking Documents and Handling Complaints against Executive Operations in Rastin Banking.

Article I4 - The hearing sessions in the preliminary and appeal committees are recorded via installing closed-circuit cameras or multimedia facilities with the audio-visual recording capability and saved in suitable auxiliary memories, and a copy will be attached to the file.

Article I5 - All offenses and violations of all the members of the preliminary and appeal committees, related to their assigned tasks, are heard by the disciplinary court of judges by virtue of this law. In case the disciplinary court recognizes the decision of the appeal committee in contrary to the laws, or verifies commitment of an effective crime or violation, after hearing the case and issuing the decision according to the attributed offense, it will reverse the issued decision of the appeal committee and inform the director general of the Central Bank for referring the executive case to the appeal committee.

Article I6 - The head of the BDEU is elected from the experienced personnel of the bank, who hold bachelor degree in judicial law, or an equivalent or a higher degree, and is introduced to the State Organization for Registration of Deeds and Properties to pass the necessary educational and training courses and will be assigned as the head of the BDEU in case of showing the required scientific qualification. The head of the BDEU, while responsible for managing execution of the banking documents, supervises the good performance of the executive operation based on the Bylaw for Enforcement of the Purports of Binding Banking Documents and Handling Complaints against Executive Operations in Rastin Banking, and is also responsible for the issuance of executive order, order, and signature of the transfer document draft for registration and signing in notary public offices.

Article I7 - Bank, as the holder and beneficiary of the cheque and the other binding documents, for those mentioned documents, which have been acquired based on execution of Rastin Banking Act, according to this chapter of the law and the Bylaw for Enforcement of the Purports of Binding Banking Documents and Handling Complaints against Executive Operations in Rastin Banking, can issue the writ of execution and collect the sum of the document through the BDEU. 
3. The Proposed Bylaw for Enforcement of the Purports of Binding Banking Documents and Handling Complaints against Executive Operations in Rastin Banking

\section{Section I: Definitions}

Article I - The words and terms applied in this bylaw are defined as follows:

I.Binding document: It is an official or ordinary document, by which the writ of execution can be issued for the enforcement of the purports of the document without the need for issuing a decision from the court.

2.Binding banking document: It is a binding document, where the obligee is the bank.

3.Debt document: It is a document, which discloses the obligation of the debtor to pay cash money, or to deliver goods, or to perform a specific action, and in the registration terms, it is applied against the transaction documents with refund right.

4. Collateral document: It is a document, which implies a mortgage contract, or a transaction with refund right, or a sale, by virtue of which the person (whether s/he is the debtor or not) gives his/her movable and immovable property as collateral for doing an action, whether the action is payment for a claim, or is another action.

5.Executive order: It is an order to execute the binding banking documents, which is issued by the BDEU.

6. Executive transfer document: After the bid, the property underbid is transferred to the winner of the bid or the creditor by virtue of the official document, which is called the executive transfer document.

7. Seizure: It is means the seizure of properties for enforcement of the purports of the document.

8.Protector: It is the person who is trusted by the BDEU to protect and keep the seized property.

9. Official expert: $\mathrm{S} /$ he is the person, who can make comments based on his/her knowledge, experience, and skills in a particular discipline in the issues relating to his/her field of specialization as an expert, and has the permission from the qualified authorities for this activity.

I0. Surplus: In registration terms, surplus is the price of the property, which is surplus to the claim of the creditor, and since it is not evident that the seized or pledged property of the first creditor whether will have a surplus after bidding for the payment of his/her claim or not, it has been also known as the potential surplus.

II. Waiver of the mortgage: It means that the mortgagee bank, under special conditions, waives its collateral in order to facilitate vindication of the legal and contractual rights and by observing the laws and regulations. In this case, its debt with collateral is converted to debt without collateral, and the bank mortgage document is converted to a debt document, for which the executive regulations of debt documents will be observed.

12. Redemption of mortgage: It is the release of the mortgaged property from the mortgage, whether through giving the debt or remission of the debt by the debtor.

13. Cancelation of the document: It means to register the dissolution of the official document of a transaction, based on the formalities stipulated in the Registration Law of Deeds and Properties, and in the same office, where the document has been registered.

I4. Bid: It is a particular form of selling the property, which starts with the property valuation price and is transferred to the highest bidder.

I5. Bank Documents Execution Unit (BDEU): The unit, which enforces the purports of binding banking documents and, in brief, is called the BDEU in this bylaw.

16. Executive representation: The representation given by the BDEU to the BDEU of another area, in which the domicile of the debtor or the properties of the debtor are positioned, based on the scope of the laws and regulations for the performance of the executive affairs.

17. Travel banned person: $\mathrm{S} /$ he is the debtor (including the main or the special obliged party), who is travel banned, at the request of the creditor bank according to the regulations, because of the failure in introducing a property or impossibility of accessing to his/her property.

18. Refund right: It is the right by virtue of which the debtor can fully possess the pledged property by paying the claim of the creditor.

19. Execution fee: It is the right, in the form of money, which is received by the bank for enforcement of binding documents and is $5 \%$ of the execution price.

20. Protection fee: It is the wage, which is paid to the protector according to the regulations.

2I. Bidding fee: It is the fee, which is received from the debtor for the costs of the bid operation according to the regulations.

22. The deposit account for execution of banking documents: It is an account, which is opened in the creditor bank and under the title of the BDEU, and all funds resulting from the executive operation are deposited in it. 


\section{Section 2: Issuance of the Writ of Execution}

Article 2 - The issuance of the writ of execution is requested in order to enforce the purports of binding banking documents at the request of the related unit in the creditor bank and through the following authorities:

I.Regarding the binding official documents, registered in the notary public office: Through the same notary public office, which has drawn up the document.

2.Regarding the binding documents, drawn up in the bank: Through the BDEU.

Article 3 - The application form is drawn up according to a special form and must include the following points:

I.Name, identification code, postal code, email address, and domicile of the requester of the writ of execution, and for the official documents, the number and the registration area of the notary public office, in which the document has been registered.

2.Name, surname, birth certificate number, place of issuance, father's name, date of birth, national code, the domicile of the obliged party and in case of death of the obliged party, his/her heirs' identification information. In case one of the heirs is incapacitated or absent, the name and specifications of the legal representative of the incapacitated or absent person should be determined. Regarding the legal entities, the specifications and addresses of the domicile of the obliged person or his/her legal representative should be mentioned.

3.A subject for which the execution has been requested, in case of having any explanation, it should be indicated.

4. The claim for the damage of delayed payment should be expressed if the creditor bank is entitled to receive it based on the Rastin Banking Act and its executive bylaw.

5.The documentation number and the date of the request of the writ of execution.

Article 4 - Bank should insert the amount of its claim as well as the legal rights according to the Rastin Banking Act and its executive bylaw, separately in the application letter of issuance of the writ of execution.

Article 5 - Regarding the official documents, the notary public after authenticating the requester and verifying that $\mathrm{s} /$ he is qualified for requesting the issuance of the writ of execution, prepares the copy of the document in three special sheets with legible handwriting within 24 hours (in case the obligor is one person; if there is more than one obligor or if the collateral does not belong to the obligor, two copies will be added for each one of the obligors and the collateral owner) and writes down the subject to be executed in its special place (in case there is no problem in its issuance) within 48 hours of receiving the application request, and signs and seals the writs of execution with the special seal of "for execution", sends it to the BDEU for execution, receives the receipt, and the executive operations will start.

Note I: In case the notary public faces any problem in the issuance of the writ of execution, $\mathrm{s} /$ he shall prevent its issuance and inquire from the district registration unit by expressing the problem, and the mentioned office shall guide him/her, and in case the district registration unit faces any issue, it shall inquire from the province registration unit about its duties. The enquired registration unit, including the district or the province units, is obliged to respond within I0 working days.

Note 2: The writ of execution can be only issued for the obligations, which have been explicitly mentioned in the document.

Article 6 - The BDEU is obliged to enquire from the Collateral Registration System (CRS) about the registration status of the collateral and its specifications and record the requested response along with the inquiry tracking code in the records.

Article 7 - Notary public offices are obliged to mention the issuance of the writ of execution under the remarks of the related registration and in the Collateral Registration System (CRS) by stating the date, at the time of issuing the writ of execution (any kind of binding documents).

Article 8 - In collateral documents, in case the holder of refund right (including the principal debtor or the transferee) transfers his/her refund right, by mentioning the creditor's right (bank) and stating the expiry date of the documents with permission of the bank, the writ of execution shall be issued and followed against the last transferee.

Article 9 - In case the writ of execution has been issued before notification of the obligor's bankruptcy to him/her, and the executive measures have been already taken, the preliminary decision of bankruptcy will be canceled and this decision will be final, and thus, there would be no need for revision of the previous legal operation.

Article 10 - The BDEU should register the received writs of execution based on the order of the receiving dates in its special book. 


\section{Section 3: Notification}

Article II - The BDEU, after receiving the writ of execution, by observing Article IO of this bylaw, should insert in the necessary books and form a file for it, and in case the obligor resides in the region of activity of the authority of issuing the writ of execution, the name of the notification agent should be written on it and it should be submitted to the agent for notification. If the obligor resides in another region of activity, the writs of execution will be sent within 24 hours to the local BDEU, where the obligor resides. With respect to the residents in foreign countries, it will be sent by the Central Bank to the Ministry of Foreign Affairs to be notified according to the regulations.

Note: For delivering the writ of execution, notice, or other related letters, the BDEU can use the agents of the Post Company or the other non-governmental companies by signing the necessary contracts according to the regulations.

Article 12 - The notification agent shall submit a copy of the writs of execution to the obligor within 48 hours of receiving them and receive the other copy as the receipt, by stating the date with all letters. If the obligor refuses to sight or sign the writ of execution, the agent will certify the case personally and in writing; also, if the obligor was not present at the place of residence, the agent shall notify one of his/her relatives or servants, who is resident in that place and whose apparent age is sufficient for understanding the importance of the writ of execution, provided that there would be no conflict of interests between the obligor and the person who receives the writ of execution. If the said persons are illiterate, their fingerprints should be stamped at the bottom of the writs of execution and other sheets, and in case they cannot give the receipt for any reason, the agent will mention this point under his/her own responsibility, and in case these persons were not present at the place or did not give the receipt, the agent should affix the writ of execution to the domicile of the obligor and write down the premises in the other copy.

I.Regarding companies, the writs of execution are notified to the manager of the company or to the signatory, and in case of dissolution of the company, to all the liquidators of the company. In case the said persons refuse to sight or sign the writ of execution, the agent will certify the premises personally and in writing. If the said persons were not present in the place, the writs of execution, as the case may be, will be affixed to the domicile of the company or the address of the liquidator(s) according to the dissolution notice of the company.

2.Regarding ministries, governmental departments, government-affiliated organizations, public institutes, municipalities, foundations and institutions, the writs of execution are directly sent to the responsible-in-charge of the ministry, department, organization, institute, or municipality via the special delivery. In this case, the writs of execution are regarded as notified after $\mathrm{IO}$ days of submitting the writs of execution to the post, by observing the notes, stipulated in the code of civil procedure.

3.If the residence place of the obligor of the document has been specified as a governmental department, the affiliated organizations, or non-governmental public entities, the writ of execution will be notified at that place according to the regulations.

4.In case the address of the obligor has been specified as a PO Box, one writ of execution will be sent to the PO Box by the special delivery and regarded as notified after the elapse of IO days from the submission date to the post office.

5.For the documents, in which the email address has been mentioned besides the domicile of the obligor, the writ of execution will be also notified through email, of course in the departments that use computer systems. In such a case, the writ of execution is regarded as notified after the elapse of 48 hours after the date of submission.

Note I: The notification agent shall not have a blood or family relationship, up to the third degree of the second class, with the person to whom the writs of execution or other notices and sheets are notified, or against him/her, the executive operations are performed, and there should not be any conflict of interest, executive file, or criminal or civil claim between the agent and the notified person.

Note 2: The notification agent shall write and sign the name and specifications of the person to whom the writ of execution has been notified and also, his/her relationship with the obligor, and the place and date of notification by indicating the hour, day, month, year, and his/her own name and specifications, with fixed ink, legible terms, and with all letters, in the copy that s/he will submit it to the BDEU.

Article I3 - In all binding documents, the domicile of the transactors should be clearly expressed in the document. The domiciles of the transactors are the same addresses that have been mentioned in the document and all the writs of execution and notices are notified to the place, which has been indicated in the document, until they announce the change of the mentioned domicile, prior to the issuance of the writ of execution to the notary public office, and prior to the notification to the BDEU, by mentioning the correct address and name of street, alley, and municipality number of their residence place, such as house, shop, workplace, etc. to which the writ of execution can be notified, and the obligor cannot offer any excuse that $\mathrm{s} /$ he has not been 
aware of this issue. This is also the case regarding email address and PO Box. The notary public offices, after issuing the writ of execution, are obliged to inform the obligor via the special delivery at his/her latest address and deliver the sheets of the writ of execution, plus the receipt of the special delivery along with the other documents for forming the file and notifying the writ of execution and performing the executive operation, to the BDEU, in return for the receipt.

Article I4 - The obligor shall submit proof of his/her residence in the place that s/he introduces as his/her new domicile, to the notary public office, which has drawn up the document, or to the BDEU, and receive the receipt in return. The remarks that do not rely on written evidence will not be taken into consideration. It can include an official document, which proves the change of the domicile, or a police force certificate for the cases inside the country, or a certificate from the consulate or political officials of Iran for the cases outside the country.

Article I5 - In case the residence place of the obligor has not been determined in the document, or the specified place is not real or has been destroyed for some reasons and cannot be essentially known, the writ of execution or notice shall be published only once in one of the widely circulated newspapers of the place, or if no newspaper is available in the area, in the widely circulated newspaper of the nearest district, and it should be expressed in the respective notice that the executive operation will be performed within 10 days of the publication of the notice.

Article I6 - In case the obligor dies before issuance of the writ of execution, and the request for issuance of the writ of execution is made against the heirs, the writ of execution will be actually notified to them in the domicile of the deceased person. In case the actual notification would not become possible in the said place to any of them, or a person who has not been actually notified in the said manner, has not announced his/her domicile and the bank also cannot determine his/her domicile in such a way that an actual notification becomes possible, notification of the writ of execution will be made by observing Article I5 of this bylaw through publication in newspapers.

Note I: In case the obligor dies after issuance of the writ of execution, and before the notification, the manner of notification to the heirs will be based on the mentioned manner.

Note 2: In case the bank cannot identify and introduce the legal heir of the obligor, the National Organization for Civil Registration, the Ministry of Economic Affairs and Finance, and any other informed institution or organization will make the necessary cooperation in response to the bank inquiry in this regard.

Article I7 - In case the obligor is minor or incapacitated, the writ of execution and the other executive operations will be notified to his/her guardian, as the case may be.

\section{Section 4: The Order of Execution}

Article I8 - From the date of notification of the writ of execution, the obligor shall enforce its purports within IO days, or shall make the arrangements for payment of his/her debt, or shall introduce a property, which makes the execution of the document possible.

Article 19 - The price of the property, introduced for seizure, should be commensurate to the debt, and its permissibility from all the aspects should be verified for the vindication of the binding subject.

Article 20 - Upon the permission of the obligee, it would not be problematic to introduce claims by the obligor, even though the claims are overdue.

Article 2I - A third party can introduce his/her property for the execution of the writ of execution. In this case, after seizure by the BDEU, the introducer will have no right of withdrawal. Introducing the third party's property through the debtor of the document, by proxy on behalf of the owner, is permissible, if the official power of attorney explicitly expresses this matter. In this case, the client is not entitled to demand for a refund of the seized property after the seizure.

Article 22 - Introduction of a property by the debtor or a third party will not prevent the seizure of the other properties by the obligee. In this case, the equivalent of the properties, which have been previously seized, will be released from seizure.

Article 23 - The BDEU can supply the payment of the executive claim from the obligor's properties, prior to the expiration of the period, stated under Article I8 of this bylaw. In this case, the BDEU will seize the equivalent of the binding subject from the obligor's properties, immediately after notification of the writ of execution.

Article 24 - If the writ of execution has been issued for submission of the exact movable property, and the obligor does not 
submit it within IO days after notification, the document BDEU officer will confiscate the exact property and its benefits (if the writ of execution has been also issued for the benefits) and submit it to the related unit in the bank, and receive the receipt slip in return, unless the property has been possessed by another person and the possessor claims for possession of the property or its benefits. In this case, the BDEU officer will not remonstrate, and the obligee can refer to the court. If the writ of execution has been issued upon submission of a registered immovable property and the possessor claims for the right of its benefits by virtue of the court's judgment or an official document issued by the owner (which has predated the obligee's document), the property will be delivered to the obligee through observing the rights and possessions supported by a judgement or an official document. In case the obligee has any objection to this case, $\mathrm{s} /$ he can refer to the court.

Article 25 - In case the subject of the writ of execution is the exact specified movable property and the property is not accessible or is under obligation, and the obligor refuses to perform the obligation, or the exact one cannot be found outside, the obligee can claim for the price of the date of execution of the obligation. In this case, the BDEU officer will determine the said price through an official expert and receive it from the obligor, unless otherwise has been agreed in the document between the parties, and therefore, the agreed action will be performed accordingly.

Article 26 - In case the writs of execution are referred by the BDEU to the other BDEUs in Tehran or in other cities, the referred BDEU shall act according to the regulations of this bylaw.

Article 27 - In any case that the executive representation is given according to Article 26 of this bylaw, the representing BDEU is not allowed to follow its own executive operation and shall look for the actions under representation until it is informed of the result of the actions of the referred party. But if the obligee introduces a property of the obligor and it is proved for the representing BDEU that the subject of representation has not been performed by the referred BDEU, seizure of the introduced property will be permissible and in this case, the obligee will inform the referred BDEU immediately in order to not take any further action for this purpose.

Article 28 - The person, who guarantees the performance of the obligor's obligations, shall be able to perform the related responsibilities, and in case of refusal, the executive responsible will vindicate the object of guarantee according to the regulations.

Article 29 - In case the writ of execution has been issued for performing an obligation, such as repair of a building or a duct, or completion of a new building or a construction, or plantation of trees and the like, and the obligor does not perform his/her obligation after notification of the writ of execution, the BDEU will bind the obligor to perform the obligation or pay the necessary expenses for performing it, after receiving the viewpoint of the official expert.

Article 30 - In case in the document, any amount of money has been specified as the penal clause for delayed execution of the obligation, the claim for the penal amount will not prevent the claim for execution of the obligation, but if the penal amount has been specified for non-performance of the obligation, the obligee can only claim for one of them.

Article $3 \mathrm{I}$ - Attorney's fee of the attorney, or of the legal representative, can be claimed and collected in case of interference in all the executive actions until the stage of collection, on the basis of the concluded contract between the parties, and up to the price, expressed in the amendment bylaw of the Attorneyship Law, and at the request of the beneficiary; in the case of the collateral documents, the collateral, itself, will be used for the attorney's fee as well.

Article 32 - Discharge of the debtor from the debt, with regard to the damage or a part of the principal, will not prevent issuance of the writ of execution and evaluation and bidding of the entire collateral, and in case the purchasing company does not participate in the bid and the object of collateral is transferred to the creditor, the discharged price will be refunded to the debtor or remitted in an account, opened in the bank for this purpose.

Article 33 - Regarding the property, which has been seized against some claims by the BDEU, the surplus seizing creditor, who has seized through the BDEU, can remit all the debts and legal expenses of the obligee in the related account at the BDEU, and after transfer of the documented rights of the obligee's claim to the said person, the said person can vindicate his/her claims through the BDEU.

Article 34 - Regarding the property, which has been seized against some claims through the BDEU, the surplus seizing creditor can remit all the debts and legal expenses of the antecedent seizing parties, and also the other accrued legal fees in the deposit account of the BDEU and request for confiscation of the property and vindication of his/her rights from it. In this case, the seizures will be released, and the property will be collected for a part or whole of his/her claim, and the total remitted amount will be immediately seized by the State Organization for Registration of Deeds and Properties and sold through bidding and 
according to this bylaw.

Note: In all executive cases, in which the object of bidding is transferred to the creditor, the debtor can pay his/her debt before drawing up and signing the executive transfer document or delivering the property, as the case may be.

Article 35 - Cost of notice, expert wage, protection fee, execution fee, and bidding fee for movable and immovable properties, in addition to the other legal expenses shall be paid by the obligor and are collected the same as the principal claim.

\section{Section 5: Seizure of Movable Properties}

Article 36 - Seizure of the obligor's property will be done in the presence of the BDEU officer and the representative of the public prosecutor and if necessary, in the presence of a police officer with the coordination of the BDEU. The absence of the obligor or his/her relatives and servants, and also a closed place, where the property is located, will not prevent the seizure of the property. In valuing the introduced properties for seizure, the BDEU officer is obliged to receive the official expert's view.

Note: The officer is obliged to make the necessary arrangements before the seizure for determination of the protector.

Article 37 - In case the debt and appurtenances are valued up to one-hundred million Rials, and the introduced property is seemed not to be more than the said price at the discretion of the BDEU officer, the property of the debtor will be seized without the expert's view. Otherwise, the BDEU officer will ask for the opinion of the official expert at the time of seizure and seize the equivalent property, plus one or two additional tithes of the obligor's property. In addition, if the seized property is not divisible and is more than the said amount, then all of it will be seized.

Article 38 - The property, which should be seized, is seized where it is located and transferred to a safe place, if necessary. Anyway, the seized property should be surrendered to the protector, and the BDEU officer is the person to select the protector. The BDEU officer shall assign the protector.

Article 39 - Objection of the person, who receives the seized property as the protector, will not be effective in the preliminary committee for handling complaints against executive operations, after acceptance of the property as the protector.

Article 40 - The protector shall have enough assets and guarantee to protect the property, and if possible, without transferring the seized property to another place.

Note: If the BDEU officer commits a fault in the selection of a trustworthy protector and/or any other condition relating to the trustee, $\mathrm{s} /$ he will be jointly considered responsible along with the protector.

Article 4I - The BDEU officer cannot deposit the seized property to the following persons:

I.To his/her relatives, up to the third degree of the second class.

2. To the obligor and his/her spouse, and to the persons who have a blood or family relationship, up to the third degree of the second class, with the obligor and his/her servants or employers, unless any other person is not found for protection of the seized property.

Article 42 - The BDEU officer gives a copy of the minute for the seized properties to the protector and receives the receipt at the bottom of the minute. The BDEU officer gives a copy of the property minute to the obligor or obligee, upon their requests.

Article 43 - The protector has the right to claim for the protection fee (including the rental costs and etc.), commensurate to the value of the seized property. The head of the BDEU discerns the commensurability, and if it is proved that the protected property belongs to a third party, the obligor shall pay the protection fee. The official expert can be employed for determining the protection fee.

Article 44 - If the executive operation is ended, and the property owner refuses to receive it and does not refer, and the protector is not satisfied with the continuation of protection, the BDEU shall sell it through bidding at any price, which finds a purchaser, and remit the amount to the related account at the bank under the name of the owner, and the protection fee will be paid from that source. This subject should be notified to the property owner prior to the bidding through a notice.

Article 45 - The protector should deliver the property in case of requesting the property by the BDEU, and in case of refusal or fault, s/he is considered the guarantor and regarded as the principal debtor, and the BDEU will vindicate the equivalent amount of the seized property from the protector's asset and in case necessary, the change of the protector will be based on the view of 


\section{the BDEU.}

Article 46 - In case the seized property has benefits; the protector shall also protect them and be accountable for them as well. In case the protection requires paying an immediate cost before receiving the permission of the BDEU, the protector can pay from his/her own funds and take it into account by submitting the related documents to the BDEU.

Article 47 - In case they want to seize a part of the obligor's property and the obligor or his/her relatives are absent, a detailed list of the remaining properties should be taken by mentioning all the specifications, and if they want to take the seized property out of the place where the other properties of the obligor are located, the BDEU officer shall determine a reliable person for protection of the other properties of the obligor.

Article 48 - Seizure of the benefits is permissible.

Article 49 - Seizure of the debtor's rights, toward the goodwill, is permissible; however, it is not allowable to put it into bidding considering the benefits of the third parties, unless after receiving their consent. In case the benefits or goodwill are seized, the premises shall be notified to the Registration Office of the district to be registered in the seizure book and notified to the related notary public offices.

Article 50 - Seizure of the debtor's rights, toward the goodwill and benefits, does not prevent seizure of any other found property, belonging to the obligor. In such a case, if the seized property is equivalent to the credit of the creditor, the rights will be released from seizure.

Article 5 I - In case the debtor of a debt document has a claim over a third party based on the collateral; it is permissible to seize that claim from the third party. In this case, the seizing party will be the surrogate of the creditor with collateral and will use the rights of the collateral holder, according to the regulations of collateral documents.

Article 52 - In execution of the debt documents against the heirs of the deceased, it is permissible to seize the properties of heirs in compliance with Article 226 of the Non-Litigious Matters Act (NLMA), unless the heir has passed the estate of the deceased and passage of the estate of the deceased has been done and clarified in compliance with Articles 249 and 250 of the NonLitigious Matters Act.

Article 53 - The following properties and objects are the exceptions of debt, which are not seized:

I. The house, commensurate to the needs of the obligor and the persons under his/her financial support.

2.Clothes, objects, furniture, and appliances, which are necessary for fulfilling the needs of the obligor and the persons under his/her financial support.

3.Provisions, which are required for the obligor and his/her family for 3 months.

4.The working tools and equipment of traders, merchants, and farmers, commensurate to their own subsistence and the persons under his/her financial support.

5. Other properties and objects, which cannot be seized by virtue of some special laws.

Note I: In case of the death of the obligor, the debts will be vindicated from all the properties left from him/her, without any exception.

Note 2: In case of disagreement on commensurability of the properties and objects with the needs of the said persons, the head of the BDEU will make a decision considering the special condition of the obligor and the local custom, according to Article I56 of this bylaw.

Article 54 - It is prohibited to seize a movable property, whose transfer does not legally require to be registered in any notary public office or in any other competent authority, and is under the possession of another person and the possessor claims its ownership.

Article 55 - Prior to the seizure of properties, they should be listed in a way that the names and specifications of all seized objects and the financial rights are written and in case necessary, the weight and number of the objects should be determined, and for gold and silver items, if their purity is determined, it should be mentioned in the minute and for jewelry items, the number, size, specifications, and names should be determined. For books, the name, writer, and date of printing, and for canvas and paintings, the subject of the canvas, its length and width, and name of the painter should be mentioned, if evident. Also, for merchandises, the number of packages should be mentioned, and for the seizeable financials rights, the remarks should be expressed. For the shares and valuable papers, the number, the main price, and their type should be defined in the minute; also, 
the newness or oldness of the items should be indicated in the detailed list of objects.

Note I: The number, size, and weight should be written in all letters, and the minute shall be signed and sealed by the BDEU officer.

Note 2: If there are some errors or unintentional mistakes in the list of objects and remarks, it will be expressed at the bottom of the minute and signed by the BDEU officer and the attendants. Change, deletion, erasure, and writing between the lines are prohibited.

Note 3: The minute, if possible, will be written on the printed sheets.

Article 56 - The potential surplus to the collateral or to the seized property can be confiscated, and is calculated by summing up the following figures:

I.The principal claim, profit, and damage for the delay by observing the Rastin Banking Act.

2.Bidding fee.

3.Execution fee.

4.Attorney's fee, if it is a part of the contract mentioned in the document.

5.The insurance fee and other expenses, which have been paid by the creditor with collateral (and the person that against his/her claim, the principal property has been seized), which according to the regulations of this bylaw, they are entitled to receive them from the obligor.

Article 57 - In case the third parties claim any right toward the objects, which are seized, the BDEU officer mentions the name of the claimant as well as his/her manner of declaration.

Article 58 - In cases that the obligor or the representative of the public prosecutor and the witnesses are present, the full list of objects will be also signed by them, and in case they refuse to sign, the premises will be mentioned in the minute.

Article 59 - The said persons in the previous article can make their objections on the drawn up minute to the BDEU officer, and the BDEU officer will mention their comments in the minute accompanying the rejecting or accepting causes.

Article 60 - In case the movable properties are protected in a safe and defined place, the BDEU officer signs and seals the entrance, and in case the objects are not in a safe and defined place, s/he affixes a paper to each one of the objects and seals; the obligor can also seal it beside the seal of the BDEU officer.

Article 6 I - In case the duration of seizure may cause the deterioration of some items, such as carpet, wool cloths and etc., the said objects should be separated and seized in such a way that they can be inspected and controlled.

Article 62 - In case the obligor is one of the couples, who lives in one house, the household items that are usually used by the women are considered the wife's property, and those normally used by the men are considered the husband's property, and the remaining items will be regarded as shared between the couples, unless the otherwise is proved.

Article 63 - In case the seized property is shared between the obligor and the other persons; their shares will be considered equal unless otherwise is proved.

\section{Section 6: Seizure of the Properties with the Third Party}

Article 64 - In case the BDEU is informed that the cash funds or the movable properties of the obligor are held by a third party, the funds and properties, equal to the obligation of the obligor plus the other executive expenses, will be seized, and the seizure warrant will be actually noticed to the third party and also to the obligor according to the regulations; whether the third party is a real person or a legal entity, and also whether his/her debt is matured or unmatured.

Article 65 - In case the said third party in the previous article has political immunity; the seizure warrant will be sent by the Central Bank through the Ministry of Foreign Affairs.

Article 66 - Notification of the seizure warrant binds the third party not to deliver the seized money or property to its owner; otherwise, the BDEU will charge him/her the equivalent money or price of the property. This point should be indicated in the seizure warrant. 
Article 67 - In case the seized property, held by the third party, is cash money or a matured debt, the said person shall deposit the amount in the related account in the bank and receive the receipt in return.

Article 68 - In case a third party, who has seized the mature property or claim of the obligor, refuses to remit it, his/her properties will be seized according to the regulations of this bylaw.

Article 69 - In case the third party denies the presence of the whole or a part of the cash money or the other movable properties by him, s/he shall inform the head of the BDEU within I0 days of notification of the seizure warrant; otherwise, s/he will be responsible for paying the money or submitting the property, and the BDEU will collect the money or receive the property from him/her.

Article 70 - In case the third party denies the presence of the property or the claim of the obligor with him/her and informs the BDEU within the period stipulated in the above article, the executive operation related to him/her will be stopped, unless the BDEU holds acceptable and strong documents for proving the presence of money or property or claim with the third party, which has been denied by him/her.

Note: The third party, who denies the holding of the property or the claim of the obligor, can submit his/her opposition along with the proving documents to the head of the BDEU; in case of refusal of the BDEU, to the preliminary committee for handling complaints against executive operations.

Article 7I - The regulations of the above articles will be also binding, when the rental of the movable or immovable properties, belonging to the obligor, are held by the renter. In this case, the money shall be gradually returned to the aforesaid person until depreciation of the claim of the obligee is amortized, and if it is necessary to temporarily keep the said money, it should be deposited at the BDEU.

Article 72 - It is prohibited to seize the travel expenses of government officers as well as the salary and benefits of the military forces that are on the battlefield.

Article 73 - One third of the salary and benefits of the employees of the government or government-affiliated departments, organizations and institutions, governmental companies, municipalities, banks, companies, entities, foundations, private firms and so forth, and also the retirees, pensioners, and armed forces will be seized; and in case they have some persons under their financial support, one fourth will be seized.

Article 74 - Regarding the previous article, after notification of the seizure warrant to the respective department or workshop of the debtor, the head of the department or workshop and the person responsible for financial affairs (in fact, in the institutions with an authority of financial affairs) should deduct and send the seized price upon the request; otherwise, s/he will be responsible according to the regulations. This point should be written in the seizure warrant.

\section{Section 7: Seizure of Immovable Properties}

Article 75 - Immovable properties, including the principal and surplus items, are seized according to the instructions mentioned in Articles 36 and 37 of this bylaw; and the BDEU officer will prepare the list of seized properties, with the following information on the printed sheet:

I.Date and purports of the writ of execution.

2.Location of the property in the city, block, district, street, alley, and number, if available.

3.Four bounds of the property and its brief description.

4.Estimated area of the property.

5. Other specifications, such as the number of parts in case of a residential house, or the number of buildings and appurtenances in case of agricultural property. In addition to the above premises, its appurtenances, such as cattle, machinery, and other remarks, which are effective in the facilitation of the sale of the property, shall be mentioned in the said list.

Article 76 - In case the bounds or a part of the property is contentious, the details shall be mentioned in the minute, and it shall be expressed that who is the disputing party, and where the dispute is under investigation.

Article 77 - The BDEU shall immediately notify the obligor about the seizure and also the local Registration Office, and ask for the status and the registration process of the seized property. In case the property has been already registered, the local 
Registration Office shall write down the seizure of the property in the seized property book and note down the seizure under the remark column of the property registration book. Also, if the property belongs to another person by virtue of the contents of the property registration book and its transfer to the obligor is not proven, the Registration Office shall immediately inform the BDEU.

Article 78 - In case the seized property has not been registered; the following alternatives will be applied:

I.In case the obligor has requested for registration of the said property, and it has not been yet transferred to another person according to the official document, or its owner is unknown, seizure shall be mentioned in the seizure book and recorded in the registration file.

2.In case another person has requested for registration of the said property, and the property has not been yet transferred to the obligor, or basically, the object of seizure is not among the places, which have been given for public registry, the premises will be informed to the BDEU.

Article 79 - After notification of the seizure warrant to the property owner, transfer of the seized property by the property owner is prohibited, and transfer after seizure, while the seizure still continues, will not be effective (although the transfer has been performed with the official document), unless upon the permission of the person for whom the property has been seized to protect his/her rights, the stakeholders will decide if the property shall be continued to be seized or released.

Article 80 - Seizure of an unregistered immovable property under the name of the debtor, which is possessed by another person, even though the obligee claims the ownership of the obligor or the obligor claims for his/her ownership, is prohibited while this claim has not been proven by virtue of the final decision. With regard to the properties that have been registered in the property registration book and based on that, the property is recognized as the obligor's property, the claim of the third party, even though s/he possesses the property, is not hearable, and the property will be recognized as the obligor's property and be seized.

Article 8I - Seizure of an immovable property that for its interests, no obligation in favor of any other person has been made, requires the seizure of its benefits unless there is no need for their seizure. In this case, the details should be reflected in the minute.

Article 82 - In the seizure of the product of the agricultural properties, it is prohibited for the BDEU officer to interfere in the product, until the harvest and determination of the share of the obligor, but the BDEU shall have full supervision and control in order to prevent dissipation.

Article 83 - In the two following cases, the obligor can sell the movable or immovable seized property or give it as collateral by informing the BDEU.

I.In cases that before or at least, during the conclusion of the transaction, the amount for which vindication, the property has been seized, is paid in cash, the property will be released from seizure, immediately after the vindication of the obligor's right and the execution cost.

2.In case of providing a written consent of the obligee for selling or giving the property as collateral by the obligor.

Article 84 - The immovable property, after the seizure, will be temporarily remained under possession of the owner, and the obligor shall take the delivery of the immovable property based on the list and deliver it according to the list.

Article 85 - In case of seizure of the benefits of the immovable property or seizure of the harvested crops, it will be subject to this bylaw, in terms of determination of the protector and the other issues.

Article 86 - In case a third party claims the right toward the seized property (including movable and immovable), the bid will be prevented in the following cases:

I.In case the obligee accepts the objection of the third party.

2.In case the third party presents an official document, predating the seizure, indicating that the seized property has been transferred to him/her, or is mortgaged to him/her, or is collateral for his/her claim.

3.In case the property has been confiscated before the date of seizure, for supplying evidence, or by virtue of the writ of execution of the court, or by the Registration Execution Unit for the claim of the objector.

4.In case the third party presents an irrevocable or revocable decision of the court regarding his/her legitimacy.

5.In case the request for registration has been accepted for ownership or endowment before the seizure.

6.In case the subject has been recognized as expressible at the Supervisory Board or Higher Council of Registration, due to the complaint of the objector. 
Regarding the above cases $I$ and 2 and also 4, the property will be released from seizure, in case of the presence of the final decision, and in other cases, the continuation of the executive operation is postponed until the final decision against the objector is made in the related authorities. The obligee can ignore the seized object and request for seizure of the other properties of the obligor.

Note I: In case each of the said cases in this article is realized after holding the bid, and before issuance of the transfer document or delivery of the movable property, the BDEU will cancel the bid minute and then, act as mentioned in the above article.

Note 2: In case specifications of the bidding property do not conform to the purports of the document, or to the documented decision of the third party, his/her objection will not prevent the executive operation, and the third party can refer to the court.

Article 87 - The obligee can introduce the property of the obligor, which has not been demanded registration in order to vindicate his/her own claim. In this case, after bidding and expiration of the moratorium, the Registration Office, with the notification of the BDEU, will transfer the document to the bid winner according to the applicable regulations, and it is mentioned in the notice, minute, and transfer document that since no request for registration of the property has been received, the Registration Office does not have any duty to deliver the subject of transfer and moreover, is not responsible for any problem, such as objection, that may occur during acceptance of the registration request or after it. The transferee should request for registration according to the applicable regulations and shall pay all expenses of the executive actions, which have been accrued for the seizure of the property, and the previous executive case will be followed according to the regulations.

Note I: Eviction and delivery of the properties, under this article, to the bid winner, will be performed by the BDEU.

Note 2: Introduction of an unknown property, before acceptance of the request for registration by the obligor, is not accepted.

\section{Part 8: Evaluation}

Article 88 - In any case that a property is identified or introduced (including the seizure for debt documents or a collateral case for evaluation), the identified or introduced property will be evaluated by the evaluator of the BDEU and the evaluation minute will be notified to the owner or debtor after confirmation by the head of the BDEU. In case the stakeholder (the owner or the debtor to the bank) objects to the valuation price, s/he can register his/her objection in the execution book or in the preliminary committee for handling complaints against executive operations within $\mathrm{IO}$ days of the notification date and receive the receipt in return. The mentioned offices are obliged to inform the objection to the head of the BDEU at most within 48 hours of registration of the objection. The head of the BDEU will issue the order for referring the evaluation to the board of three official experts of the Administration of Justice.

Article 89 - The view of the board of three official experts of the Administration of Justice is appealable in the preliminary committee for handling complaints against executive operations within $\mathrm{IO}$ days of submission to the BDEU or notification to the owner or debtor.

Article 90 - The preliminary committee for handling complaints against executive operations refers to the evaluation of the mentioned property to the board of five official experts of the Administration of Justice. The decision of the latter board about evaluation will be final. Election of the members of the expert boards, under Articles 88, 89, and 90 of this bylaw, will be performed by a lucky draw.

Article $9 \mathrm{I}$ - The evaluation fee shall be paid by the objector, and if both sides are objectors, the half amount shall be paid by each party.

Article 92 - In any case that a property is introduced by the obligor or by the third party and is seized, the obligee can introduce another property for the vindication of his/her claim before the publication of the bid notice, provided that collecting the claim from this property would be easier. In this case, the introduced property will be seized and evaluated, and the equivalent amount of the previously seized properties will be released from seizure. The seizure and re-evaluation costs shall be paid by the obligee.

Article 93 - The objector will refer to the BDEU within IO days, become aware of the wage of a new expert and deposit it, submit the related slip to the BDEU, and receive the receipt in return. In case that the result of the evaluation is notified according to Article 88 of this bylaw, the wage of a new expert shall be included again. In case the addressee objects to the evaluation, s/he shall submit his/her written objection to the preliminary committee for handling complaints against executive operations within IO days of notification by attaching the expert's wage deposit slip. In case the objection would not be delivered as indicated above, the evaluation will be final. 
Note I: In case the objection is valid, the wage of the expert shall be paid by the debtor.

Note 2: In case one year has passed from the final evaluation of the immovable property, prior to drawing up the bid minute, reevaluation can be performed upon the request of each of the parties.

Article 94 - Wage of the evaluator is determined considering the scientific and experimental degree of the official or local expert, the place of evaluation, type of the evaluated property, and the workload, on the basis of the custom of the place and the related tariff.

\section{Part 9: About Collateral}

Article 95 - In case the object of collateral is movable, the BDEU can seize it immediately after notification of the writ of execution.

Article 96 - In case a property is pledged for a debt or a guarantee and does not have any title of mortgage and transactions with refund right, all the executive regulations of the mortgage documents and transactions with refund right will be effective for it.

Article 97 - In case the collateral's benefits have been transferred to the pledgee by rent, the writ of execution, which is issued for the collection of remuneration, is like the writ of execution of the debt documents and the obligee can request for seizure of the other properties of the obligor.

Article 98 - In cases the pledger is not the principal debtor, notification of the writ of execution and the other executive operations shall be performed toward supporting the collateral owner and the debtor.

Article 99 - In mortgage transactions, or the transactions with refund right, and performance bonds, in case of agreement of the prior creditor, the transactor can give the object of the transaction as collateral or support for the other loans, by mentioning the right of the creditor and also the expiry date of the prior document, and in case of redemption of the prior transaction, the whole transacted property will be set as the collateral of the next creditors, by order of priority. The subsequent transactions should be performed in the same notary public office, which has drawn up the prior document. The notary public shall mention the performance of the latter transaction, by mentioning the full specifications of the creditor of the surplus transaction in the remarks of the prior document registration. The holder of refund right, including the principal debtor or the transferee, may transfer his/her refund right by mentioning the creditor's or creditors' right and also the expiry date. In this case, the writ of execution and the executive operations shall be issued and followed against the last transferee, unless the mortgagee revokes the mortgage, or based on the insertions of the mortgage document or another official document, the notary public office proves that there has been an agreement between parties that the mortgagee, and not the transferee, would issue the writ of execution against the mortgagor for collecting his/her claim; it is like when it is stipulated in the mortgage document that the mortgagor is not entitled to convey the rights or transfer the refund right, and in such cases, the transfer of the refund right to another person will not be effective for the mortgagor and the writ of execution will be issued and followed against the principal debtor, and in case of his/her death, against his/her successor.

Note I: In the above cases, in case one of the prior or posterior creditors is the bank, the purports of all the documents, which are drawn up as described in this article, shall be enforced by the BDEU.

Note 2: In case the bank requests the notary public office, which has drawn up the document, to issue the writ of execution, the said notary office, while notifying the other creditor(s), is obliged to receive the requests for issuing their writs of execution, issue the writ of execution, and enforce the purports of all documents. In case of failure to receive the necessary response with in 20 days of the notification, the notary public office will issue the writ of execution for the binding banking document. Failure of the other creditor(s) to request the issuance of the writ of execution on the due date would mean the waiver of the collateral, and the related document will be converted to a debt document. Enforcement of the purports of the said debt document will be possible through referring the creditor to the competent court.

Note 3: It is prohibited and ineffectual to draw up any document between the debtor and one or more creditors, which would lead to time extension of the document or increase of the mentioned price of the document without an agreement with the posterior creditors.

Article I00 - The posterior creditor of the transaction, after the expiry of the prior document, can pay or deposit the whole debt under the subject of the prior document before issuance of the writ of execution of the said document. Terms of payment or depositing money, issuance of the certificate, and reflection of the premises in the registration file of the property, will be as 
described in Article I35 of this bylaw, and the notary public office that draws up the document will mention the property as a collateral in the book, in return for the creditor's claim for the posterior transaction, and the paid money for the prior creditor's claim. In this case, the issuance of the writ of execution will be based on both the claim and its appurtenances.

Article IOI - The creditor of the posterior transaction can pay or deposit the whole debt under the prior document before selling the property through bidding or drawing up the property transfer document to the prior creditor, and request the BDEU to vindicate his/her rights. In this case, the executive operation is performed for both documents concurrently, and in case, the term of the posterior creditor document has not been matured, the executive operation will be performed after the maturity date, as described in Article 135.

Article I02 - After notification of all the issued writs of execution and returning them, if there would be no defect in notification of the writ of execution, the auditor or the executive expert shall authenticate it on the notified copy through performing the necessary investigations and get the approval of the head or deputy or the person in charge of the BDEU.

Article I03 - The mortgagee can waive the mortgaged object, while the mortgager is still obliged due to his/her debt. Whenever waiver occurs before issuance of the writ of execution, the mortgagee shall attend the respective notary public office in order to indicate and sign the description of the premises in the remark column of the document registration book. Afterward, by explaining the subject of waiver, the writ of execution will be issued. If waiver occurs after issuance of the writ of mortgage execution, the details should be informed to the BDEU in written, and the head of the BDEU, after proving the correctness of assignment of the said application form, shall notify the obligor and operate according to the rules of the collateral documents.

Note: By drawing up the bid minute, the right of waiving the mortgage by the mortgagee is revoked.

Article I04 - In case waiver of the mortgage is done during the executive operation; the BDEU is obliged to notify the details to the notary public office, where the document has been drawn up. In this case and also, in the case that the waiver is performed in the notary public office, the notary public office shall submit the letter of cancelation to the Office for Registration of Deeds. If the document date is not expired, as soon as the waiver is done, the mortgaged case will be released and the exact right of the obligee will be converted to a claim right, and the claim for payment and issuance of the related writ of execution will be subject to termination of the period, stipulated in the transaction document. In case the debtor has heirs and also in case there are a number of mortgagers and redemption of the mortgage and cancelation is subject to payment of all the debts, the waiver of the mortgage shall be done against the entire mortgaged cases. The waiver of the mortgage, for the shares of one or more of the debtors, can be only accepted when the debt claim rights of those debtors, whose mortgaged cases have been waivered, have been revoked from the other debtors, and if the surplus of the mortgaged case has been seized in favor of a third party, in case of waiver of the mortgage, the surplus seizure will be converted to the seizure of the principal.

Article I05 - In case the surplus of the pledged property is seized by the BDEU or the other legally competent authorities, the details should be recorded in the seizure book as soon as the notice of seizure is received. The seizure will be realized as soon as the respective notice is submitted to the debtor or as soon as the purports are registered in the seizure book. Whenever the transaction, by virtue of which the surplus of the pledged property has been seized, is canceled, the surplus seizure is automatically converted to the seizure of the principal. In any case, the purports of the seizure shall be immediately notified to the notary public office, where the document has been drawn up, and the notary public office is obliged to mention the purports in the remarks of the transaction registration, and if the transaction document has resulted in issuance of a writ of execution, the details shall be accordingly notified to the related BDEU.

Article I06 - In case a part of the collateral has been destroyed before or after issuance of the writ of execution and the creditor is still committed to the pledged case, the collateral still remains valid, according to the price of the part, which is still remained based on the evaluation, and for the other part, the process will be performed according to the debt documents.

Article 107 - In cases that due to certain regulations, the collateral gets owned by a third party before termination of the executive operation, or because of insufficiency of the collateral, the obligee does not receive his/her whole claim, the obligee can follow through the BDEU to collect the remainder of his/her claim, in accordance with the executive regulations of the debt documents.

Article 108 - In case the collateral really or with order is destroyed, the document is subject to the regulations of the debt documents.

Article I09 - Separability of the transacted or seized property (including movable and immovable) is discerned by the BDEU.

Article IIO - Forcible grant of the refund right to the heirs of the debtor does not lead to separation of the object of the (c) (1) \$ 38 
transaction. Whenever, before issuance of the writ of execution or before termination of the executive operation, all the deb ts, legal damages, and execution fee, in case of issuance of the writ of execution, are paid by some heirs of the debtor, the mortgage of the transacted property shall be redeemed. The said heir(s) have the right to refer to the other heirs for payment of their debts.

Article III - In case after notifying the writ of execution to the debtor, occurrence of the debtor's death is announced according to an official certificate, the BDEU shall affix a notice, including the writ of execution and the report about the current stage of the executive operation, to the domicile of the deceased debtor. If the writ of execution has been published in the newspaper, then the said announcement should be also published once in the local or the nearest widely circulated newspaper. In this case, drawing up the bid minute or the transfer document, and also registering the property in the property book under the name of the purchaser or the creditor, does not require the issuance of the probate certificate. With regard to the above case, whenever the property is sold in the bid, paying the surplus to the heirs is due to submitting the probate certificate and acquittance of the Ministry of Economic Affairs and Finance.

Article II2 - If one of the heirs pays the debt of his/her testator, s/he can request the other heirs to pay their shares of the paid debt and refer to them for the vindication of his/her rights.

\section{Section 10: Bidding}

Article II3 - In the enforcement of the collateral or debt documents, after evaluation of the property and finalization, the bid notice shall be published in accordance with the following terms and conditions:

A. The Bid Notice for Immovable Properties:

In the bid notice for immovable properties, the followings notes shall be stipulated:

I. First name and last name of the owner;

2. Location, borders, area, and a brief description of the respective property;

3. Whenever transfer of the benefits occurs in the collateral documents supported by the official document and in the debt documents supported by the official or the ordinary document, whether its due date has been terminated or not, the details of the rent property and the rent termination date shall be stipulated in the bid notice published in the newspaper, and also in the affixed notices;

4. Indication of whether the object of the bid is a shared or separated property;

5. Indication of whether the property is registered or not;

6. It should be indicated that the payments of electricity, water, and gas utility, which include the membership or subscription fees and usage payments, if the subject of the bid is related to them, and also tax liability and municipal charges and etc., until the date of the bid, whether the final amount has become known or not, will be on the bid winner;

7. Day, location, and starting and finishing hours of the bid;

8. Bid base price.

\section{B. Bid Notice for Movable Properties:}

In the bid notice for immovable properties, the followings notes shall be stipulated:

I. Type of the properties under the bid subject and their brief description;

2. Day, location, and starting and finishing hours of the bid;

3. Bid base price.

Article II4 - The bid notice shall be published once in a local widely circulated newspaper, and in case there is not one in the district, in a widely circulated newspaper of the nearest district. The period between the publication and the bid date shall not be shorter than I5 days. Along with this notice, some notices shall be prepared and affixed on the property building, the bid place, and public buildings such as the municipality, sheriffdom, governorship, police force, the Administration of Justice, and the Office for Registration of Deeds of the district. Additionally, it shall be published on the professional website for property bidding. For the properties, which are bid at a price lower than IOO million Rials, only an affixed notice and publishing on the professional website for property bidding shall suffice. 
Article II5 - In case the object of collateral is multiple properties, located in different regions of the country, the bid notice shall be affixed in all the mentioned areas, and the bid area shall be stipulated in the notice with a full address.

Article II6 - In case the bidding property has been insured; this shall be stipulated in the bid notice. In case the bidding property is transferred to another party, the insurer shall be announced.

Article II7 - At the end of the bid, if there is a surplus, the bid winner can return the money under paragraph 6 of clause A of Article II3 of this bylaw, from the mentioned surplus. In case the bidding property is transferred to the creditor, all the abovesaid expenditures shall be paid by the creditor and will be deemed as his/her claims, and are collectible with the same writ of execution.

Note: Whenever the bid notice is in contrary to Articles II3-II6 of this bylaw, it shall be revised by order of the head of the BDEU before drawing up and signing the bid minute.

Article II8 - The bid is performed in person or on the internet. An in-person bid shall be held in one session from 9 to 12 o'clock. If the property in the seizure or the collateral does not receive any purchaser in the bid session, the property, after deducting the execution and the bidding fees, will be transferred to the creditor bank for the bank's claims and the incurred legal costs.

Note I: The bank is obliged to sell the owned property in compliance with the laws and regulation for selling the state properties within 4 years after the end of the executive operation and after deduction of the bank claims and the related costs and remuneration of the mentioned period, and return the rest of the transaction price to the stakeholder. In case the bank does not aim to or cannot sell the owned property as explained and during the indicated period, in case of request of the stakeholder or his/her legal representative, the bank is obliged to carry out a revaluation of the property, and pay the difference of its claims and the incurred costs, and the price of the property to the stakeholder in cash, unless the parties have made any other agreement by a mutual consent.

Note 2: The bid on the internet will be made in compliance with the bylaw, which will be prepared by the State Organization for Registration of Deeds and Properties and approved by the head of the Judiciary Power.

Article II9 - The BDEU, in addition to the necessary administrative books, will have the termination book, and the timetable book of bids.

Article I20 - The head and employees of the BDEU, the sales foremen, representative of the attorney general, and the appraiser are not allowed to directly or indirectly participate in the bid as a customer.

Article I2I - All persons can attend the bid session, and it will be held by the presence of the head of the BDEU, the bid manager, and the representative of the attorney general.

Article I22 - The bid manager shall indicate the bid time (by mentioning the day and hour) in the draft of the bid notice and in the timetable book of bids.

Article I23 - Handwritten books, treatises, and articles of any writer cannot be seized or bid, unless by his/her own consent.

Article I24 - Bidding of spoilable properties and animals, which are introduced for vindication of a claim, shall be immediately made by the order of the BDEU head in the area and without any formality by the BDEU officer and in presence of the representative of the attorney general in accordance with the viewpoints of a formal or a local expert.

Article I25 - The bid minute shall be signed by the related authorities, the representative of the attorney general, purchaser, debtor, and creditor, or their legal representatives if present.

Article 126 - In the bid, the property cannot be sold on credit.

Article I27 - By virtue of the rules and regulations, delivery of the movable property to the bid winner, receipt of the execution fee and the other legal fees, and payment of the surplus amount shall be performed by the BDEU officer. Ordering to prepare the draft of transfer document and registering and signing in the notary public office in accordance with the regulations for movable and immovable properties shall be performed by the head of the BDEU.

Article I28 - In the following cases, the sale shall not be valid, and the bid notice shall be re-published according to related the rules and regulations: 
I. Whenever the sale is not performed on the day, hour, and place, stipulated in the bid notice;

2. Whenever a purchaser is illegally inhibited from purchasing the property, or the property is not transferred to the highest bidder;

3. Whenever the bid is made in the absence of the representative of the attorney general;

4. Whenever the foremen or the other persons, stipulated in Article 120 of this bylaw, have not attended the bid session.

Article 129 - Movable properties are delivered to the purchaser immediately after collection of the execution fee and in the bid session, and a copy of the bid minute shall be submitted to him/her; if the executive transfer document is legally required, a draft of the transfer document shall be prepared.

Article I30 - For immovable property, after the bid session, within 48 hours, the BDEU officer shall make a list for the file and staple it, and send the report attachment to the head of the BDEU for issuance of the transfer document draft. After draft issuance, the head of the BDEU shall order to send it to one of the notary public offices for the purpose of drawing up the executive transfer document.

Note: After drawing up the executive transfer document in the notary public office, the BDEU will take the necessary actions for eviction and delivery of the bid property, according to the rules and regulations.

Article I3I - For mortgage transactions, whenever there are multiple debtors and mortgagers, and the bid notices have been sent on different dates, the posterior date of notification is deemed as the start of the I0-day period.

Article I32 - The bid operation shall not be stopped, except for the following cases:

I. Receipt of a writ of judgment or a temporary order or a writ of attachment for the executive operation;

2. Objection to the decision of the BDEU head until the issuance of the final decision by the committee for complaints against executive operations;

3. Issuance of the decision of the preliminary or appeal committees for annulment of the executive operation;

4. Payment of all the debts of the creditor and the executive fees.

Article I33 - Whenever the bid subject includes multiple properties, if there is a separate purchaser for each of the properties and the total purchasing price is more than the claim of the creditor, the sale shall be performed and the minute will be prepared. In case the income from selling some properties is sufficient for remittance of the debt, the minute for other properties shall not be drawn up. In such a case, the debtor can request the priority of selling one or some of the properties.

Article I34 - In all the transactions, stipulated in the revised Article of 34 of the Registration Law, the debtor can provide the arrangements for cancelling and redeeming the document by depositing all his/her debts including the principal, the gains and the legal loss to the account of the Registration Office, and submitting the related documents to the notary public office, where the document has been drawn up. In case of issuance of the writ of execution, the certificate of the BDEU regarding the permission for redemption and cancelation of the transaction is necessary. Any creditor, who has the right to confiscate the debtor's properties, can also pay all the debts and the executive rights, and request for the vindication of his/her rights from the BDEU.

Article I35 - In all the transactions, stipulated in the revised Article 34 of the Registration Law, the creditor, who has the right to request for confiscation of the debtor's properties and who aims to pay all the debts and the executive rights (in the case of issuance of the writ of execution), the transaction object will be confiscated until the payments for both the debts and the legal appurtenances are made, and the premises shall be recorded in the seizure book of the Registration Office by the BDEU announcement. In this case, the followings shall be observed:

I. In case of issuance of the writ of execution, the debts, damages, and executive rights shall be asked from the related BDEU and determined accordingly. Then, it should be deposited in the deposit account of the BDEU, and the receipt shall be submitted to the BDEU, and the request for cancelation of the document shall be made.

2. As soon as all debts, damages, and executive rights are paid, the BDEU is obliged to immediately notify the premises to the notary public office, which has drawn up the document, in order to cancel the document. The BDEU shall concurrently inform the related registration unit to register the details about the seizure of the transacted property in favor of the person, who has paid the debt, in the seizure book. If the respective file is not there, the necessary certificate shall be issued about depositing the money and issuance of the order of cancelation by indicating the deposited amount, the name of the payer, and the number of the letter, in which the seizure has been submitted to the relevant registration unit, and deliver it to the applicant. 
3. In case the executive file is going on in another department, the stakeholder shall submit the related certificate to that executive department, in which the execution file is going on, and make a request for seizure of the property. The latter department is obliged to immediately make an order for seizure of the property.

4. Whenever the transacted object is in the executive operation, and no final minute of the bid has been drawn up, or no transfer document has been issued, by depositing the amount, by the debtor or by the prior seizer of the collateral surplus, the document will be canceled and the executive file will be closed. Afterward, the premises will be notified to the notary public office, where the document has been drawn up in order to record the subject under the remarks of the document registration.

5. In the cases stipulated in the above article and Article 134, whenever the benefits of the transacted property are the right of habitation and has been transferred to the creditor, the said right shall be respected until the end of the period, indicated in the document.

Article I36 - Eviction by virtue of the purports of this bylaw is among the duties of the BDEU.

\section{Section II: Eviction and Termination of the Executive Operation}

Article I37 - In the final transfer of the property, whenever the writ of eviction is issued, and a third party lives in the property, subjected to eviction by virtue of an official rent document; the bank does not evict the building until the end of the duration, stipulated in the mentioned document.

Note I: In cases that inhibition of the third party has not been performed by virtue of an official rent document or the duration of inhibition has been expired in the document, the BDEU is obliged to evict.

Article I38 - Whenever the collateral refers to the shared part of the property, but by mutual consent, the separated part of the property has been captured by the mortgagee, the execution of the document for eviction of the mortgaged property shall be performed for eviction of the captured object.

Article I39 - Whenever the obligor's right for transfer of the benefits has been denied in the collateral document, the obligor violation will not prevent the eviction of the collateral in favor of the bid winner, even if the third party has rented the collateral on a posterior date according to the official document.

Article I40 - Whenever the collateral has a specified plaque number and the building is located inside it, and thereafter, it is realized that a part of the building is located in the neighbor ground, which belongs to another person, the whole building will be evicted. Certainly, the above measures do not prevent vindication of the rights of the neighbor ground's owner.

Article I4I - Whenever at the time of delivery, it becomes clear that a third party or some third parties have built buildings in the pledged property without permission, the deliverance of the collateral shall not be troublesome with its current situation by the BDEU.

Article I42 - If the delivery has been absolutely stipulated in the document, the property shall be allowed for eviction.

Article I43 - The BDEU officer shall perform the necessary measures, with regard to the eviction of the property, at the presence of the representative of the attorney general and if necessary, at the presence of a police officer, according to the regulations. Absence of the obligor and his/her relatives and servants does not prevent the eviction. If there are some belongings in the place of eviction, the BDEU officer shall gather a full list of them and if possible, keep them in a safe place in the same location, and lock and seal the doors, or give them to the obligee or a trustee and receive the receipt in return.

Note I: In the above case, the creditor or the trustee can charge for the protection fee.

Note 2: When the belongings are submitted to the protector, at the request of the obligee, the BDEU shall notify the owner to refer to the BDEU within a month and receive his/her properties. Otherwise, in compliance with the regulations, the belongings will be evaluated, and bid and the earned money shall be deposited in the deposit account of the BDEU, until the owner attends the bank, and the remained amount, after deduction of the executive costs, shall be refunded to him/her. In case there would not be any purchaser in the bid session, the belongings shall be continued to be kept.

Article I44 - The premises of closing the file shall be notified by the BDEU to the related notary public office in order to stipulate under the remark column of the registration book and perform the necessary measures accordingly.

Article I45 - The executive operation shall end by the following cases: 
I. Receiving all the claims of the creditor, the government rights, and the legal costs;

2. Delivery of the movable property to the bid winner;

3. Preparation and signing of the executive transfer document of the immovable property in notary public offices;

4. Realization of the eviction or delivery, in cases where the writ of execution has been issued for eviction or delivery;

5. Fulfillment of the commitment by the obligor.

Note: In case the property is sold to a third party through the bid, the termination of the executive operation will be deemed as the date of drawing up the minute.

\section{Section 12: Executive Expenditures}

Article I46 - The execution fee (i.e., the executive half tithe) shall be collected in the same way as the payment of the subject of obligation. The BDEU can adopt any other method for the payment, which seems appropriate, considering the execution fee.

Article I47 - The execution fee of the binding documents is the half tithe and shall be taken from the party that the execution is against him/her unless the creditor has made the request of execution without having any right. Half of the execution fee shall be paid to the general revenue account of the government and the other half to the revenue account of the BDEU, whether this execution fee has been received from any office, department, or branch.

Article 148 - In every executive file, after notification of the writ of execution, the execution fee shall be collected, unless the party obliged to pay is exempted from payment by virtue of certain regulations.

Note I: If the debtor enforces the purports of the writ of execution within IO days from the notification, s/he will be exempted from paying the execution fee.

Note 2: If the debtor pays all his/her debts before drawing up and signing the bid minute, half of the execution fee shall be collected.

Article I49 - In case that the document of a conflicting transaction has mistakenly resulted in the issuance of the writ of execution and notification, the execution fee will not be incurred, while the final decision on document validation has not been issued.

Article I50 - In any case that after issuance of the writ of execution and notification, the executive operation is legally suspended or interrupted, the execution fee will not be incurred, while the suspension or interruption is not ended.

Article I5I - In cases the writ of execution is issued and notified, but then submitted to the liquidation department due to the verification of bankruptcy, the execution fee is not incurred unless the decision of bankruptcy is revoked and the executive operation is finalized in the BDEU.

Article I52 - For the damages to the subject of the document, the execution fee shall be incurred. This is also the case for the attorney's fee if included in the subject of the document.

Article I53 - The obligor's discharge from the debt, wholly or partially, after notification of the writ of execution, shall not prevent the payment of the execution fee by the obligor.

Article I54 - If the obligor's bankruptcy or incapability becomes clear at the date of notification, the execution fee shall not be incurred.

Article I55 - While the bid has not held correctly, the execution fee shall not be incurred.

\section{Section 13: Complaint against Executive Operations and the Procedure of Handling Complaints}

Article I56 - After issuance of the order of execution (as soon as the execution is stamped), the executive operation will start. Anyone (including the obligor of the document and any stakeholder person), who has a complaint against the executive operation, can submit his/her complaint to the head of the BDEU through stating the reasons and presenting the proofs. The head of the BDEU is obliged to notify the preliminary committee for handling complaints against executive operations, with the attachment of a copy of the file contents.

Article 157 - The preliminary committee can make a request for further explanations from the BDEU and the subject parties, 
whenever necessary.

Article I58 - After drawing up and signing the bid minute, no complaint of the executive operation is heard from any of the parties. However, this point does not prevent that before drawing up and signing the transfer document or delivery of the property, the preliminary committee for complaints of executive operations, by virtue of the final decision, recognizes the executive operation against the laws and issues a decision to re-perform the executive operation.

Note: The preliminary or appeal committees can issue the order of suspension of the executive operation in any stage of performance, according to the purports of the file, and the complainant contents, and the proposed reasons and evidence.

\section{Section I4: Miscellaneous Affairs}

Article I59 - Regarding banks' claims, the bank shall recognize what amount of the debtor's payments is related to the principal amount of the debt. If the debtor has any objection to the bank's discrimination, the hearing authority for settlement is the committee for handling complaints against executive operations.

Article I60 - With regard to all the due dates, expressed in all chapters of this bylaw, the notification and execution days will not be counted. If the last day for enforcement is holiday, it will be ignored, and the immediate day after the holiday will be deemed as the last day.

Article I6I - The contracts, drawn up by the parties for the executive file, in the committee for handling complaints against executive operations, are valid and effectual and deemed as the binding official documents. Any of the parties can put the subject of the document into effect by the BDEU.

Article I62 - Whenever the cheque is dishonored due to a part of its price, the cheque holder has the right to request a writ of execution for payment of the remainder.

Article I63 - Whenever multiple and conflicting certificates are issued by the bank, issuance of the writ of execution is subject to settlement of the conflicts of the same bank.

Article I64 - Any claim of the cheque drawer, about the notes that are sometimes written in the cheque, such as "this cheque is drawn for ..." or also the notes endorsed on the back of the cheque about the endorser, shall not be heard in the BDEU, and only for the amount written in the cheque, the writ of execution can be issued in the BDEU.

Article I65 - Indictment against the drawer of a dishonored cheque to the competent authorities does not prevent to issue the writ of execution for collection of the amount specified in the cheque through the BDEU unless an order would be issued in this regard from the judicial authorities.

Article I66 - If the amount specified in the cheque is not paid because of the differences between the signature below the cheque and the signature of the authorized cheque drawer, or in case of legal entities, the cheque has not been sealed, no writ of execution will be issued by the BDEU.

Article I67 - In case the cheque has been issued on behalf of or via the representative of the account holder, the cheque drawer and the account holder will be jointly obliged to pay the amount specified in the cheque, and the writ of execution, at the request of the creditor, will be issued against them according to their partnership.

Article I68 - In cases that there are multiple account holders and the cheque should be signed by one of them, the writ of execution will be issued against the signer and according to the amount of the cheque.

Article I69 - With regard to post-dated cheques, the writ of execution will be issued after the due date.

\section{References}

Rastin Banking texts, available at http://www.bidabad.com

Bidabad, Bijan. (20I4). New Operational Islamic Banking System, Volume One, Theoretical Foundations, LAP Lambert Academic Publishing, OmniScriptum GmbH \& Co. KG, 20I4, ISBN: 978-3-659-54463-7. 
Bidabad, Bijan. (20I4) New Operational Islamic Banking System, Volume Two, Applicational Issues, LAP Lambert Academic Publishing, OmniScriptum GmbH \& Co. KG, 20I4, ISBN: 978-3-659-552I0-6.

Bidabad, Bijan, Mortgage Securitization System (MSS), A Complementary System of Rastin Banking. International Journal of Law and Management (IJLMA), Vol. 59 Issue: 6, pp.778-783, 2017.

https://doi.org/I0.II08/IJLMA-05-2016-0045

http://www.bidabad.com/doc/mss-paper-en.pdf

Bidabad, Bijan, Money Laundering Detection System (MLD), A Complementary System of Rastin Banking, Journal of Money Laundering Control, Vol. 20 Issue: 4, pp. 354-366, 2017.

https://doi.org/I0.I I08/JMLC-04-2016-0016

http://www.bidabad.com/doc/mld-paper-en.pdf

Bidabad, Bijan, Mahmoud Allahyarifard, Interbank Withdrawal Protocol (IWP), Complementary System of Rastin Banking 2013. International Journal of Islamic Business \& Management, 3(I), 30-34, 2019.

https://www.cribfb.com/journal/index.php/ijibm/article/view/259

http://www.bidabad.com/doc/iwp-paper-en.pdf

Bidabad, Bijan, Mahshid Sherafati, Bank Information Disclosure, Financial Transparency and Corporate Governance in Rastin Banking, International Journal of Shari' ah and Corporate Governance Research, 2(I), I - I3, 2019.

https://www.cribfb.com/journal/index.php/ijscgr/article/view/257

http://www.bidabad.com/doc/shafafiyat-en.pdf

Bidabad, Bijan, Mahshid Sherafati, Financial Transparency, Governance and Public Disclosure for Entrepreneur (Financial Resource Receiver) in Rastin Banking System. Tehran, Iran, 2015.

http://www.bidabad.com/doc/transparency-entrepreneur-en.pdf

Bidabad, Bijan, Azarang Amirostovar, Mahshid Sherafati, Financial Transparency, Corporate Governance and Information Disclosure of the Entrepreneur's Corporation in Rastin Banking. International Journal of Law and Management (IJLMA), Vol:59, Iss:5, pp.636-65I, 2017. https://doi.org/I0.I I08/IJLMA-0I-2016-0003

Bijan Bidabad, Saeid Abdollahi, Mahshid Sherafati, (2015) Proposed Regulations for Enforcement of Purports of Binding Banking Documents in Rastin Banking, Tehran.

http://www.bidabad.com/doc/rastin-bank-ejraye-asnad-en.pdf

Bidabad, Bijan, Saeid Abdollahi, Mahshid Sherafati, Enforcement of the Purports of Binding Banking Documents in Rastin Banking - Part I. International Journal of Law and Management (IJLMA), Vol:59, Iss:I, pp.52-65, 2017.

https://doi.org/I0.I I08/IJLMA-07-2015-004I

Bidabad, Bijan, Saeid Abdollahi, Mahshid Sherafati, Enforcement of the Purports of Binding Banking Documents in Rastin Banking - Part II. International Journal of Law and Management (IJLMA), Vol:59, Iss:2, pp.I78-I9I, 2017.

https://doi.org/I0.I I08/IJLMA-I0-20I5-0055

Bidabad, Bijan, Mahshid Sherafati, Sustainable Financing and Anti-Squandering Measures in Rastin Banking. International Journal of Law and Management (IJLMA), Vol. 59 Issue: 6, pp.939-949, 2017.

https://doi.org/I0.I I08/IJLMA-04-2016-0037

http://www.bidabad.com/doc/esraf-bank-resource-en.pdf

Bidabad, Bijan, Serial Commitments Clearance (SCC) in Rastin Banking, International Journal of Law and Management (IJLMA), Vol. 57, Iss: 6, 2015, pp. 600-609. http://dx.doi.org/I0.I 108/IJLMA-02-2015-0007

http://www.bidabad.com/doc/scc-paper-en.pdf

Bidabad, Bijan, Mahshid Sherafati, Operational Ethical Banking in Rastin Banking (Professional Ethics, Auditing, Inspection, 
Control, Monitoring and Preservation). International Journal of Law and Management (IJLMA), Vol: 58, Iss: 4, 20I6, pp. 4I6 - 443.

http://dx.doi.org/I0.I108/IJLMA-07-2015-0037

http://www.bidabad.com/doc/rastin-ethic-banking-en.pdf

Bidabad, Bijan, General Regulatory Framework in Rastin Profit and Loss Sharing Banking (Part I-Operational Context). Journal of Business and Finance in Emerging Markets, JBFEM, [S.1.], v. I, n. I, p. I I-26, May 20I8. ISSN 2580-5568.

https://doi.org/I0.32770/jbfem.volI I I-26

http://www.bidabad.com/doc/rastin-regulatory-en-I.pdf

Bidabad, Bijan, General Regulatory Framework in Rastin Profit and Loss Sharing Banking (Part II-Legal Groundwork). Journal of Business and Finance in Emerging Markets, JBFEM, [S.1.], v. I, n. 2, p. I09-I26, Nov. 20I8. ISSN 2580-5568. https://doi.org/I0.32770/jbfem.volI I09-I26 http://www.bidabad.com/doc/rastin-regulatory-en-II.pdf

Bidabad, Bijan, General Regulatory Framework in Rastin Profit and Loss Sharing Banking (Part III-Auxiliary Provisions). Journal of Business and Finance in Emerging Markets, JBFEM, May 2019, Vol 2, No. I, pp. 5I -65. ISSN $2580-5568$. https://doi.org/I0.32770/jbfem.vol25I-66 http://www.bidabad.com/doc/rastin-regulatory-en-III.pdf

Bidabad, Bijan, Azarang Amirostovar, Saeid Abdollahi, Mahmoud Allahyarifard, Eskandar Pordel, Maryam Heidari, Alireza Shafiei, Mohammad Ali Pourbehrouz (2012) Draft of Rastin Banking Bill, Bank Melli Iran. http://www.bidabad.com/doc/rastin-banking-bill.pdf

Bidabad, Bijan, Azarang Amirostovar, Saeid Abdollahi, Mahmoud Allahyarifard, Eskandar Pordel, Maryam Heidari, Alireza Shafiei, Mohammad Ali Pourbehrouz (2012) Draft of Rastin Banking Executive Regulation, Bank Melli Iran. http://www.bidabad.com/doc/rastin-banking-regulation.pdf

The Bylaw for Enforcement of the Purports of Binding Official Documents and Handling Complaints against Executive Operations in Rastin Banking, The Bylaw for the Reform Law of the Law of Holding the Public and Revolutionary Courts, Ratified on 29.01.2003

The Bylaw for Enforcement of the Purports of Binding Official Documents, Amendments of Articles 34, 35, 36, Quoted from No. I8509, 14.09.2008, Official Gazette No. I/87/5553, 09.09.2008.

Najafi, Iraj. (2010). The Role and Position of Notary Public Offices in Enforcement of the Purports of Binding Official Documents, Notaries Monthly Journal, No. IO4, http://www.notary.ir/content-news-letter/436

\section{Copyrights}

Copyright for this article is retained by the author(s), with first publication rights granted to the journal. This is an open-access article distributed under the terms and conditions of the Creative Commons Attribution license (http://creativecommons.org/licenses/by/4.0/). 